\title{
First data of Iberian Nematomorpha, with redescription of Gordius aquaticus Linnaeus, G. plicatulus Heinze, Gordionus wolterstorffii (Camerano) and Paragordius tricuspidatus (Dufour)
}

\author{
Leonor Cristina de Villalobos ${ }^{1}$, Ignacio Ribera ${ }^{2} \&$ David T. Bilton ${ }^{3}$ \\ IFacultad de Ciencias Naturales y Museo, Universidad Nacional de La Plata, 1900 La Plata, Argentina; \\ ${ }^{2}$ Department of Entomology, The Natural History Museum, Cromwell Road, London SW7 5BD, UK; ${ }^{3}$ De- \\ partment of Biological Sciences \& Plymouth Environmental Research Centre (PERC), University of Ply- \\ mouth, Drake Circus, Plymouth PL4 8AA, UK
}

Keywords: Nematomorpha, Gordiidae, Gordius, Gordionus, Paragordius, parasites, taxonomy, Spain

\begin{abstract}
Four species of Nematomorpha are recorded from NE Spain, representing the first reliable data on the group in the Iberian peninsula. Gordius aquaticus Linnaeus, 1758, G. plicatulus Heinze, 1937, Gordionus wolterstorffil (Camerano, 1888) and Paragordius tricuspidatus (Dufour, 1828) are redescribed based on scanning electron microscope observations. Notes on intraspecific morphological variation and ecology of the species are given.
\end{abstract}

\section{Contents}

$\begin{array}{ll}\text { Abstract } & 73 \\ \text { Introduction } & 73 \\ \text { Material and methods } & 73 \\ \text { Systematics } & 74 \\ \text { Gordius aquaticus } & 75 \\ \text { Gordius plicatulus } & 76 \\ \text { Gordionus wollerstorffi } & 79 \\ \text { Paragordius tricuspidatus } & 82 \\ \text { Acknowledgements } & 84 \\ \text { References } & 84\end{array}$

\section{Introduction}

Knowledge of the phylum Nematomorpha in the Iberian peninsula, and in the southern Mediterranean area in general, is still extremely limited. In Gerlach's (1978) checklist five species are recorded from the Iberian peninsula south of the Pyrenees, and one from the Pyrenean area. Of these, Gordius angulatus Linstow, 1906 should be excluded because it was described from Madeira, not from continental Portugal. Similarly, Parachordodes speciosus (Janda, 1894), considered to be of a dubious taxonomic status by Schmidt-Rhaesa (1997), was described from Galizia (Poland), and its inclusion in Iberia must be a confusion with the Spanish Galicia. The Iberian records of Gordius pioltii Camerano, 1887, Parachordodes tolosanus (Dujardin, 1842), and Gordionus violaceus (Baird, 1853) were not considered by Schmidt-Rhaesa (1997) in his recent revision of the European fauna of Nematomorpha, which included only Parachordodes gemmatus (Villot, 1885), recorded from the French Pyrenees. Other records are generic (e.g. Gordionus spp. From Portugal, Schmidt-Rhaesa, 1997), or have no reliability (e.g. Codina, 1925).

Recent captures of free-living adults of Nematomorpha in NE Spain by the junior authors allowed detailed study, for the first time, of Iberian representatives of this interesting group. Four species of Gordiidae are redescribed, Gordius aquaticus Linnaeus, 1758, G. plicatulus Heinze, 1937, Gordionuś wolterstorffii (Camerano, 1888) and Paragordius tricuspidatus (Dufour, 1828). Males of G. plicatulus are described for the first time. and the redescription of G. plicatulus, G. wolterstorffii and $P$. tricuspidatus includes also for the first time scanning electron microscope observations. Some comments on the ecology and intraspecific variability of the species are included.

\section{Material and methods}

All specimens were collected in their free, post-parasitic adult stage, and preserved in $70 \%$ ethanol. Fragments of cuticle from 
the medial part of the body were extracted from specimens for light microscopy. Cuticle fragments were washed in lactophenol for 24 hours, mounted and observed with a Wild Mka 2 microscope after cleaning and removing the remains of muscular tissue. For the study with scanning electron microscopy (SEM) fragments of the specimens (mid-body, posterior and anterior end) were dehydrated in a series of increasing ethanol concentrations, critical point dried, mounted, gold-argon coated, and observed and photographed with a Jeol SLM 1000 SEM. All specimens were studied with both SEM and light microscope. Specimens studied are deposited in the Facultad de Ciencias Naturales y Museo (La Plata), the Natural History Museum (London) and the authors' collections (see Table 1 for the depository of the specimens).

\section{Systematics}

Phylum Nematomorpha

Family Gordiidae

Genus Gordius Linnaeus, 1758

Linnaeus (1758: 647)

Type species $G$. aquaticus Linnaeus, 1758

The genus Gordius is characterised by the presence of a postcloacal crescent, anterior end acuminated, posterior end round in females and with two lobes in males, and cuticular areoles flat or absent (Schmidt-Rhaesa, 1997). It has about 70 described

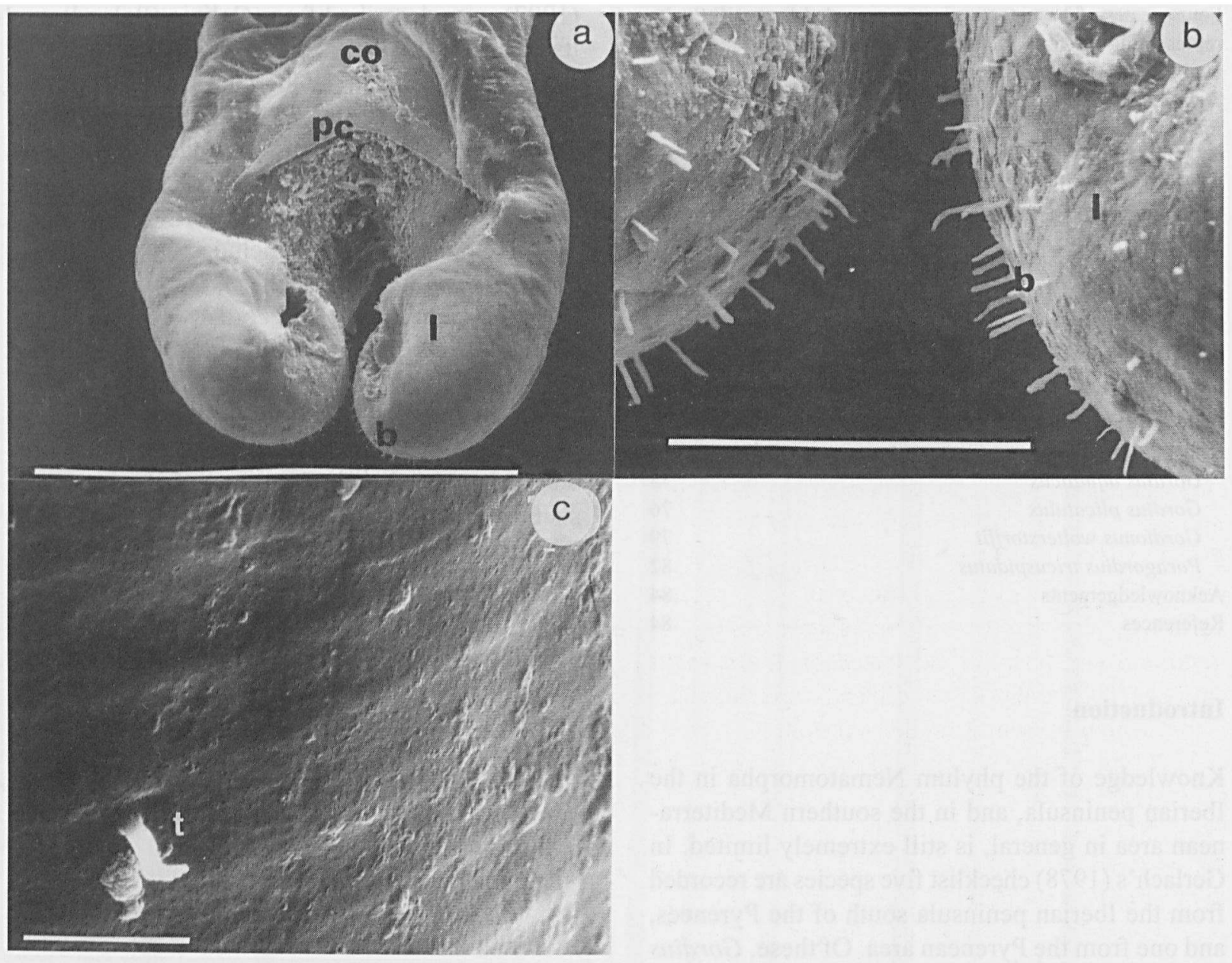

Fig. 1. Gordius aquaticus, male. A, terminal lobes and postcloacal crescent; B, apex of the terminal lobes; C, cuticle. b, bristles; co, cloacal opening; I, lobes; pc, postcloacal crescent; $t$, tubercle. Scale bar of $A=1.000 \mu \mathrm{m} ; B=100 \mu \mathrm{m}, C=10 \mu \mathrm{m}$. 
species, although a large number of them have an uncertain taxonomic status.

\section{Gordius aquaticus Linnaeus*}

(Fig. 1)

Diagnosis. - Dimensions as in table 1, from 75 to $987 \mathrm{~mm}$. Male: body colour uniform pale brown (the specimens studied had no pale spots or dark ring behind the calotte, but see comments in Schmidt-Rhaesa, 1997). Anterior end acuminate, with subterminal mouth opening. Cloacal opening oval. Postcloacal crescent with a total length from 62.2 to $723.3 \mu \mathrm{m}$, and a maximum width from $\mathbf{1 2 . 5}$ to $87.0 \mu \mathrm{m}$ in the specimens studied. Posterior lobes short and broad, between $42.3 \times 33$ and $400 \times 73.3$ $\mu \mathrm{m}$ (Fig. 1A); apex round, with sparse spiniform processes $15 \mu \mathrm{m}$ long in the inner area of the lobe, no bristles or other spiniform structures on the lateral sides of the lobes (Fig. 1B). Cuticle smooth, only marked with fine subcuticular lines (Fig. 1C), with scattered acuminate tubercles no higher than $\mathbf{5 . 3}$ $\mu \mathrm{m}$.

Female: anterior end acuminate. Posterior end not bilobed, with a central cloacal opening. Cuticle as in males. See tables 1 and 2 for the material studied.

Remarks. - The Iberian specimens of G. aquaticus differ in some characters with respect to the description given in Schmidt-Rhaesa (1997) (e.g. cloacal opening not round, with some tubercles and bristles on the tail lobes, only visible using SEM, Fig. 1B). We consider these differences attributable to incomplete descriptions or to intraspecific variation. The identity of our specimens as $G$. aquaticus was established based on the smooth cuticle and the type of post-cloacal crescent, characters which present a higher constancy.

There is a strong length variation among the specimens studied, even among specimens from the same locality (Table 2). It is unknown if this variation corresponds to differences in the host or to other environmental or genetic factors (although previous studies suggest that there is no correlation between the size of the host and the length of the parasite, Schmidt-Rhaesa, 1997; de Villalobos et al., 1999). There are no significant length dif-
Table 1. Dimensions, locality and depository of the specimens studied (see Table 2 for descriptions of the localities). FCNM, Facultad de Ciencias Naturales y Museo (La Plata); NHM, The Natural History Museum (London); DBC, David Bilton collection (Plymouth).

\begin{tabular}{lllll}
\hline Sex & $\begin{array}{l}\text { Length } \\
(\mathrm{mm})\end{array}$ & $\begin{array}{l}\text { Maximum } \\
\text { Diameter }(\mathrm{mm})\end{array}$ & Locality & Depository \\
& & \\
\hline
\end{tabular}

\begin{tabular}{llllll}
\hline \multicolumn{2}{l}{ Gordius } & aquaticus & & & \\
Female & 83 & 0.56 & 1 & NHM \\
Female & 987 & 1.1 & 4 & FCNM \\
Female & 119 & 0.70 & 4 & FCNM \\
Female & 115 & 0.65 & 9 & FCNM \\
Female & 112 & 0.61 & 9 & FCNM \\
Female & 117 & 0.65 & 9 & FCNM \\
Male & 350 & 0.79 & 4 & FCNM \\
Male & 75 & 0.49 & 9 & NHM \\
Male & 244 & 0.80 & 9 & DBC \\
Male & 420 & 0.95 & 9 & DBC
\end{tabular}

Gordius plicatulus

\begin{tabular}{lllll} 
Male & 265 & 0.82 & 4 & FCNM \\
Male & 465 & 0.94 & 4 & NHM \\
Male & 480 & 1.09 & 4 & FCNM \\
Female & 810 & 0.93 & 2 & FCNM \\
Female & 270 & 0.87 & 4 & NHM \\
Female & 268 & 0.63 & 4 & FCNM \\
Female & 164 & 0.67 & 4 & FCNM \\
Female & 267 & 0.79 & 5 & FCNM \\
Female & 164 & 0.61 & 5 & FCNM \\
Female & 920 & 1.72 & 6 & FCNM \\
Female & 270 & 0.72 & 7 & FCNM \\
Gordionus wolterstorffi & & & \\
Male & 40 & 0.51 & 3 & NHM \\
Paragordius tricuspidatus & & \\
Male & 117 & 0.81 & 8 & NHM \\
\hline
\end{tabular}

ferences between the measured males and females (as measured with a two-tailed t-Student, $p>0.5$ ).

The species is distributed in western and central Europe (excluding UK) (Schmidt-Rhaesa, 1997).

Ecological notes. - Most of the specimens were collected either in ponds in a mountain pasture (with small streams nearby) (locality 4 ) or in a mountain stream (locality 9), on different types of substratum and vegetation (Table 2). Known hosts include large species of Dytiscídae and Carabidae (Coleoptera) (Schmidt-Rhaesa, 1997). 
Table 2. Description of the localities in which specimens of Nematomorpha were found.

No. Station

1 Province of Barcelona, Caldes de Montbui, 2.12.1984, I. Ribera \& J. I. Checa leg. Small stream on a substratum of coarse sand and pebbles, no aquatic vegetation.

2 Province of Barcelona, Montseny, Turó del Home, Torrente Castellà, 23.8.1988, I. Ribera leg. Small pond in open area, ca. 30 cm diameter, $2 \mathrm{~cm}$ depth. Beech forest with abundant litter, substratum of litter, sand and stones.

3

Province of Lleida, Val d'Aran, Montgarri, river Noguera Pallaresa, 2.7.1989, 1. Ribera leg. Lateral pond ca. 2 m diameter and $15 \mathrm{~cm}$ depth, connected to the main river. Substratum of silt and fine detritus. $\mathrm{pH} 8.0$, conductivity $110 \mu \mathrm{S}$.

4 Province of Lleída, Val d'Aran, Pla de Beret, 24.9.1988, I. Ribera leg. Ponds in pasture, near the source of the rivers Garona

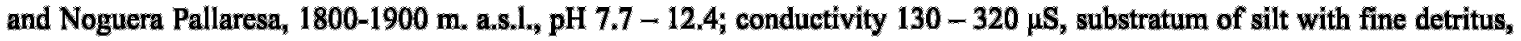
with or without vegetation, visited by cattle.

5 Province of Girona, Riera de Torrelles, 10.9.1994, I. Ribera \& P. Aguilera leg. Resídual pond in temporary river, ca. $5 \times 3 \mathrm{~m}$, $30 \mathrm{~cm}$ depth. Substratum of coarse sand, with macrophytes, with anoxic water and black silt.

6 Province of Huesca, Benasque, river Esera, 10.9.1988, L. Ribera leg. Lateral pond at ca. $10 \mathrm{~m}$ of the main channel, $10 \times 2 \mathrm{~m}$, $20 \mathrm{~cm}$ depth. Substratum of silt with some stones.

7 Province of Huesca, Sabiñanigo, river Guarga, La Calama, 14.5.1995, I. Ribera \& P. Aguilera leg. Slightly running water, shallow pools over stones and gravel, $5-15 \mathrm{~cm}$ depth. With filamentous algae. pH 7.0. (remains of $1 \mathrm{ex}$.).

8 Province of Burgos, river Arlazón, south of Pineda de la Sierra, Sierra de la Demanda. 22.07.1998, I. Ribera leg. Mountain stream, ca. $5 \mathrm{~m}$ wide, subtratum of pebbles and sand.

9 Province of Burgos, tributary of river Arlazón, ca. $1000 \mathrm{~m}$ below pass S of Pineda de la Sierra, Sierra de la Demanda. D. Bilton leg. Small mountain stream with gravel in the margins, partly shaded by Quercus trees.

\section{Gordius plicatulus Heinze}

(Figs. 2, 3)

Heinze (1937: 326)

Diagnosis. - Dimensions as in table 1 , from 164 to $920 \mathrm{~mm}$. Male: anterior apex acuminate, white, bordered by a dark collar. Mouth opening in a terminal position. Posterior end bilobed (Fig. 2A), cloacal opening oval with short circumcloacal bristles (3.6 $\mu \mathrm{m}$ height) (Figs 2A, B). Postcloacal crescent parabolic, elongated, $\mathrm{ca}$. half the length of the lobe, with a total length and width of each of the sides varying (in the specimens studied) between $22 \times 5.5$ and $40 \times 10 \mu \mathrm{m}$, and a maximum width up to ca. $10 \mu \mathrm{m}$. Lobes with a length from 57.7 to $90.0 \mu \mathrm{m}$ and a maximum width from 24.3 to $38.0 \mu \mathrm{m}$. The apex of the lobes forms a spoon shaped cavity, in which very small bristles (1.9 $\mu \mathrm{m}$ ) can be observed (Fig. 2A). One of the males had a spermatic cord (or sperm drop) $154 \mu \mathrm{m}$ long (Figs 2B, C).

Cuticle with small, narrow and irregularly scattered cuticular projections, in a generally transverse orientation with respect to the body axis. Under SEM (Figs. 2D, E) these projections appear as denticles or very thin cuticular foldings, with poorly defined edges, perpendicular to the body axis, with a length from 10.7 to $11.5 \mu \mathrm{m}$, and a height from 7.3 to $11.25 \mu \mathrm{m}$. In some parts of the cuticle these denticles are irregularly arranged, but in the medial region (Fig. 2D) they are more or less regular. Among the areoles there are scattered tubercles with round apices, $8.7 \mu \mathrm{m}$ height (Figs. 2D, E).

Anterior apex of females acuminate, with a dark collar behind the calotte. Mouth opening in subterminal position. Posterior end not bilobed, round (Fig. 3A). Cloacal opening round, in a medial depression. When observed with light microscope, the cuticle appears similar to that of males. With SEM the cuticular foldings appear narrower and more protruding, like denticles, and more densely arranged than in males (Fig. 3B).

Remarks. - The species was described with females from Freiburg, Tuttlingen and Darmstadt in Germany (Heinze, 1937), and later recorded by Canadjija (1956) from Zagreb, in Croatia, who also provided a (incomplete) description of males. There are no further records of the species, and the hosts are unknown. As with happened in the previous species, there is a large variation in size of unknown origin, but no significant differences in 


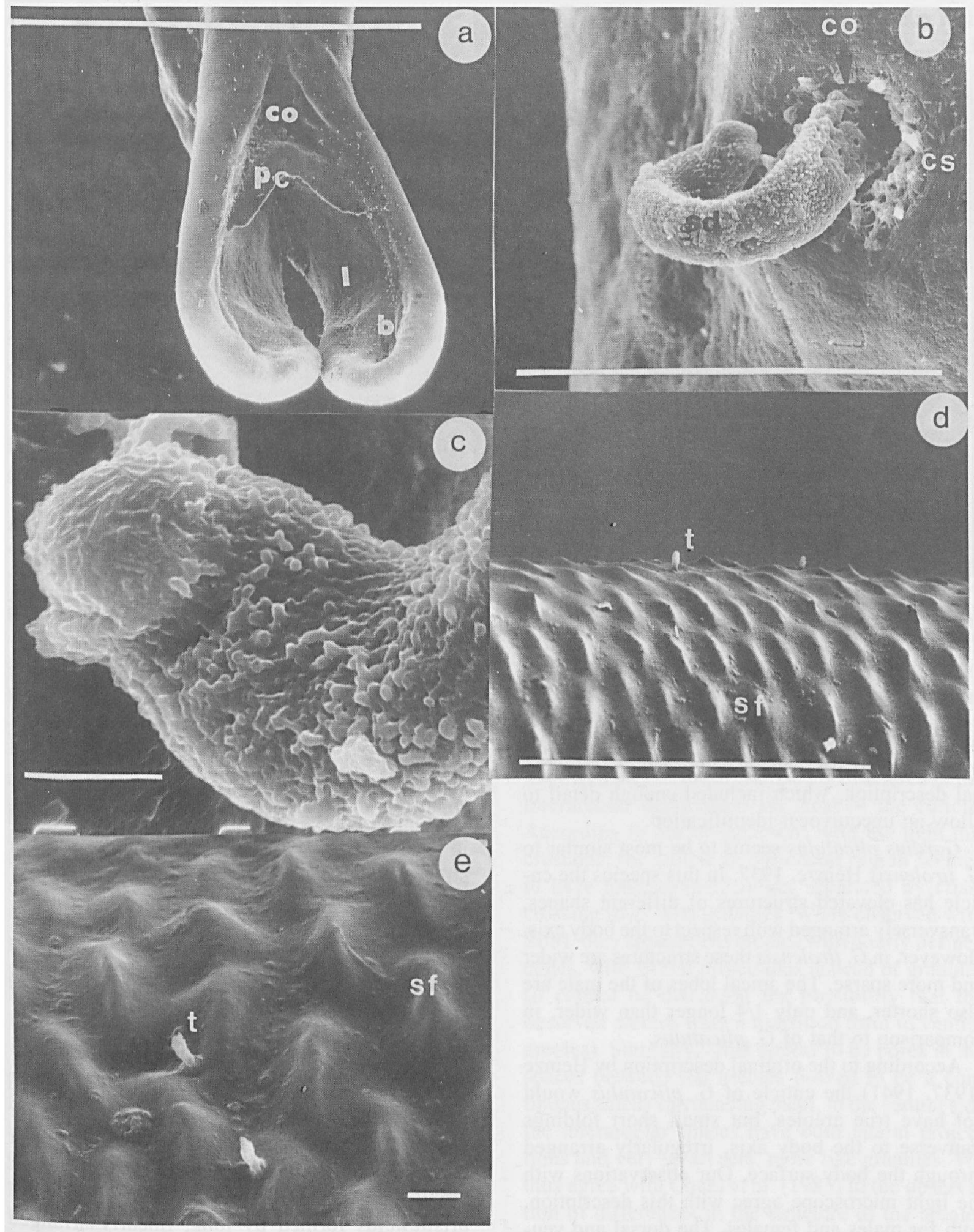

Fig. 2. Gordius plicatulus, male. A, terminal lobes and postcloacal trescent; B, cloacal opening, with the sperm drop; C, detail of the sperm drop; D, cuticle with transverse foldings; E, detail of the cuticular foldings and tubercles. b, bristles; co, cloacal opening; cs, circumcloacal spines; l, lobes; pc, postcloacal crescent; sd, sperm drop; sf, cuticlar folds; t, tubercles. Scale bars of $A=500 \mu \mathrm{m} ; \mathrm{B}$ and $\mathrm{D}=100 \mu \mathrm{m} ; \mathrm{C}$ and $\mathrm{E}=10 \mu \mathrm{m}$. 


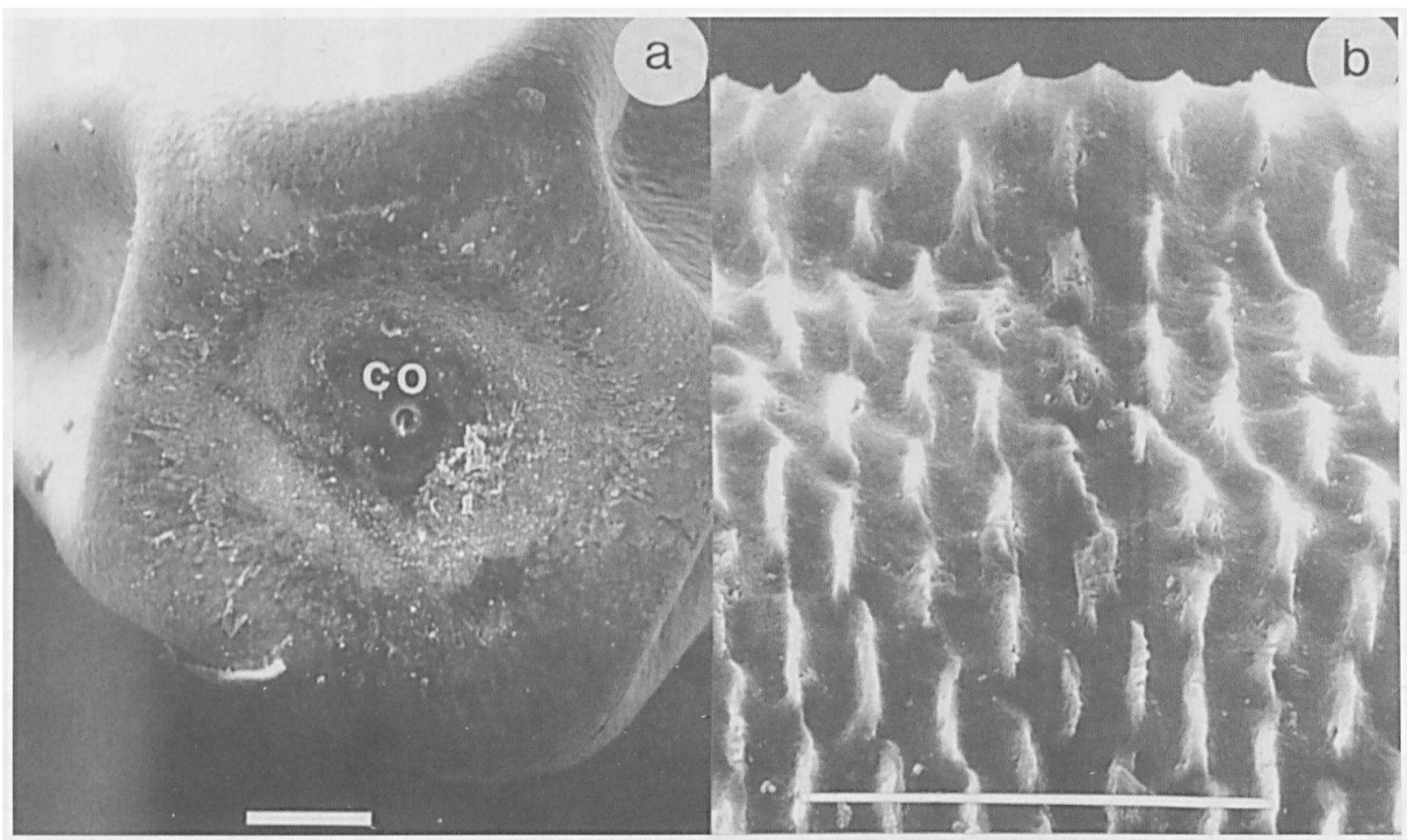

Fig. 3. Gordius plicatulus, female. A, posterior apex; B, cuticle (note the narrower and more densely packed folds, like denticles, in comparison to those of the males, Fig. 2E). co, cloacal opening. Scale bars $=100 \mu \mathrm{m}$.

length among males and females. The identity of our specimens was established based on the original description, which included enough detail to allow an unequivocal identification.

Gordius plicatulus seems to be most similar to G. tirolensis Heinze, 1937. In this species the cuticle has elevated structures of different shapes, transversely arranged with respect to the body axis. However, in $G$. tirolensis these structures are wider and more sparse. The apical lobes of the male are also shorter, and only $1 / 4$ longer than wider, in comparison to that of $G$. plicatulus.

According to the original description by Heinze $(1937,1941)$ the cuticle of $G$. plicatulus would not have true areoles, but small short foldings tranverse to the body axis, irregularly arranged through the body surface. Our observations with the light microscope agree with this description, both for males and females. The dorsal and ventral line mentioned by Heinze (1937) could not be observed.

The presence of circumcloacal bristles is par- ticularly interesting, as this is the first time they are noted for a species of the genus Gordius.

Ecological notes. - All the specimens were found in small pools associated with mountain rivers or streams, or directly in the streams (Table 2).

\section{Genus Gordionus Müller}

Type species Gordius violaceus Baird (1853: 36)

Müller (1927: 198- 199)

Diagnosis. - Anterior end usually not tapered. Mouth opening terminal or subterminal. Posterior end of the males with two lobes usually longer than wide. Cloacal opening rounded, with or without circumcloacal bristles; with two precloacal bristlefields formed by long, linearly arranged bristles; postcloacal bristles short and pointed. Females with round apex. Cuticle with a single type of areoles, either flat or protruding, poorly 
delimited in some species because of the fusion of the anterior and posterior margins (e.g. in $G$. strigatus Müller, 1927). Usually with spiniform structures in the interareolar sulcus.

Remarks. - The posterior apex of males of Gordionus is very similar to that of the species of Parachordodes, but the structure of the cuticle is clearly different: species of Parachordodes have two well defined types of areoles, one moderately protruding and the second large with a central pore. These two types of areoles are found through the body surface, without modifications in the ventral or lateral areas.

Gordionus wolterstorffii (Camerano, 1888) (Fig. 4)

Camerano (1888: 6)

Gordius pleskei Camerano (1896)

Parachordodes wolterstorffii Camerano (1897)

Parachordodes pleskei Camerano (1904)

Gordionus wolterstorffii Heinze (1937)

Diagnosis. - Dimensions as in table 1. Body pale brown. Anterior end pointed (Fig. 4A). Posterior end bilobed, with lobes (in the studied specimen) $413 \mu \mathrm{m}$ long and $146 \mu \mathrm{m}$ wide (Fig. 4B). Precloacal area (Fig. 4C) with bristle fields formed by long setae (some of them bifurcated). The bristle fields do not join above the cloacal opening. Cloacal opening oval, surrounded by short and sparse circumcloacal bristles; distance between cloacal opening and the base of the lobes $60 \mu \mathrm{m}$. Area posterior to the cloacal opening and internal side of the lobes up to the middle of their length with numerous bristles with acuminate apices, $13 \mu \mathrm{m}$ long (Figs 4D, E).

Areoles of the cuticle with some variations depending on the region of the body (as seen with light microscope), some large and others shallower, very flat in appearance, with or without defined edges. In the dorsal region (Fig. 4H) the flat areoles fuse to form long strings, with almost indistinguishable limits between them, and separated by very irregular interareolar furrows. In the ventral region (Figs 4F, G) the cuticular areoles are better defined, with granules and rounded apex setae in the interareolar furrows, with an irregular rectangular shape (length from 20.5 to $23.3 \mu \mathrm{m}$, width from 7 to $14 \mu \mathrm{m}$ ) (although in the posterior end of the body they also form longitudinally arranged strings in which the anterior and posterior limit of each individual areole are difficult to distinguish). In the posterior extreme of the ventro-lateral area (Figs 4F, G) there are oval structures ("lateral blumps" according to Cham et al., 1983; "adhesive warts" in the more recent terminology of SchmidtRhaesa, in press), at a distance about $0,6 \mathrm{~mm}$ anterior to the cloacal openning. These structures become larger, oval, longitudinally aligned, and with depressions in the interareolar spaces (as observed with SEM), with length from 17.6 to 26.5 $\mu \mathrm{m}$ and width from 4.0 to $6.2 \mu \mathrm{m}$. They are surrounded by a deep sulcus, and usually occur in pairs, alternate or aligned (but not contiguous), with spiniform structures between them.

Remarks. - Although the the species of Gordionus have only one type of areoles, Gordionus wolterstorffii has some transitional changes in the type of areoles across different regions of the body (without defining clear types).

It is interesting to note the different interpretation of the granulated structures of the areoles. Camerano (1888) and Cham et al." (1983) note a large quantity of these granulated structures in the interareolar depressions on most of the cuticle. According to our observations with the light microscope, the cuticle in the dorsal region seemed to have long elevated ridges separated by crisscrossing rows with granules. When observed with SEM, they appeared as areoles with poorly defined edges; with lateral projections instead of granules (it cannot be discarded the possibility that the observed areoles were a transition form to ventral areoles). Similarly, what appear to be pores in the spaces between flat areoles proved to be a continuous sulcus surrounding them. In the ventral side the interareolar spaces have both lateral projections and very small seta, more like granules. We thus agree with Cham et al. (1983) in the observation of differences in the structure of the areoles in different parts of the body.

The posterior apex of Gordionus wolterstorffii has the same general structure as that of $G$. 


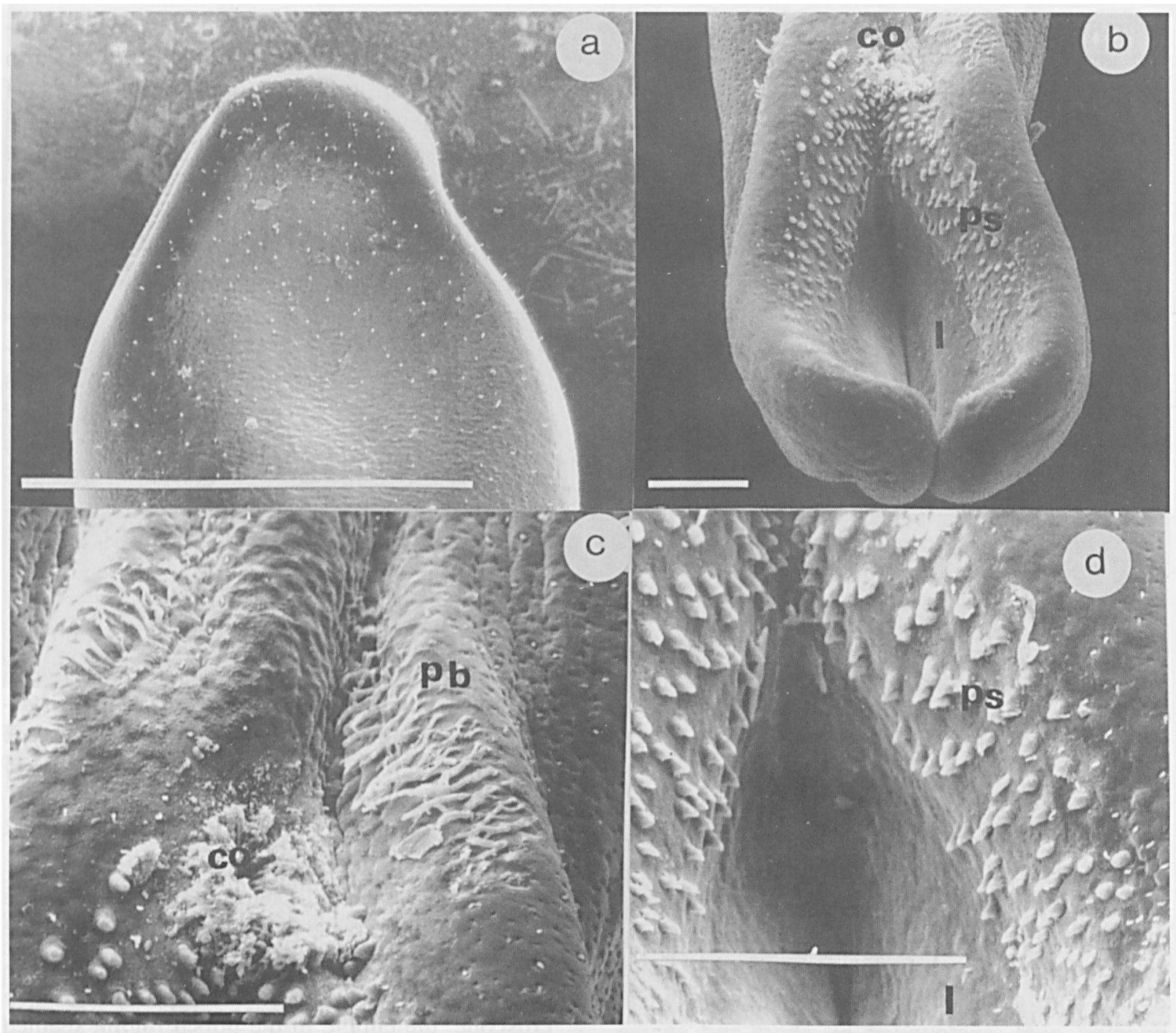

Fig. 4. Gordionus wolterstorffi, male. A, anterior apex; B, posterior apex; C, precloacal bristles or bristle fields (note the bifurcated apex of some of them); D, internal side of the terminal lobes with postcloacal spines. co, cloacal opening; if, interareolar furrow; mg, adhesive warts (or "lateral blumps"); mc, areoles; l, lobes; $p$, pores; pb, precloacal bristles; ps, postcloacal spines; s, spines. Scale bars of $\mathrm{A}=500 \mu \mathrm{m} ; \mathrm{B}, \mathrm{C}, \mathrm{D}, \mathrm{F}$ and $\mathrm{G}=100 \mu \mathrm{m} ; \mathrm{E}=10 \mu \mathrm{m} ; \mathrm{H}=20 \mu \mathrm{m}$.

violaceus, G. linourgos de Villalobos, Ribera \& Downie, 1999 and G. diligens de Villalobos, Ribera \& Downie, 1999 (de Villalobos et al., 1999), with bristle fields at the sides and anterior to the cloacal opening, and postcloacal spiniform structures along the inner side of the terminal lobes. The cuticle of all these species is, however, clearly different: $G$. violaceus has well defined round and polygonal areoles, with a large number of short hairs in the interareolar sulcus; $G$ linourgos has oval areoles and the cuticle is covered with transversal striae; and $G$. diligens has round areoles connected between them by cuticular projections crossing the interareolar sulci.

The species was previously recorded from Britain, Belgium, north Italy and central Europe (Schmidt-Rhaesa, 1997).

Ecological notes. - The single studied specimen was found in a marginal pond associated with a 


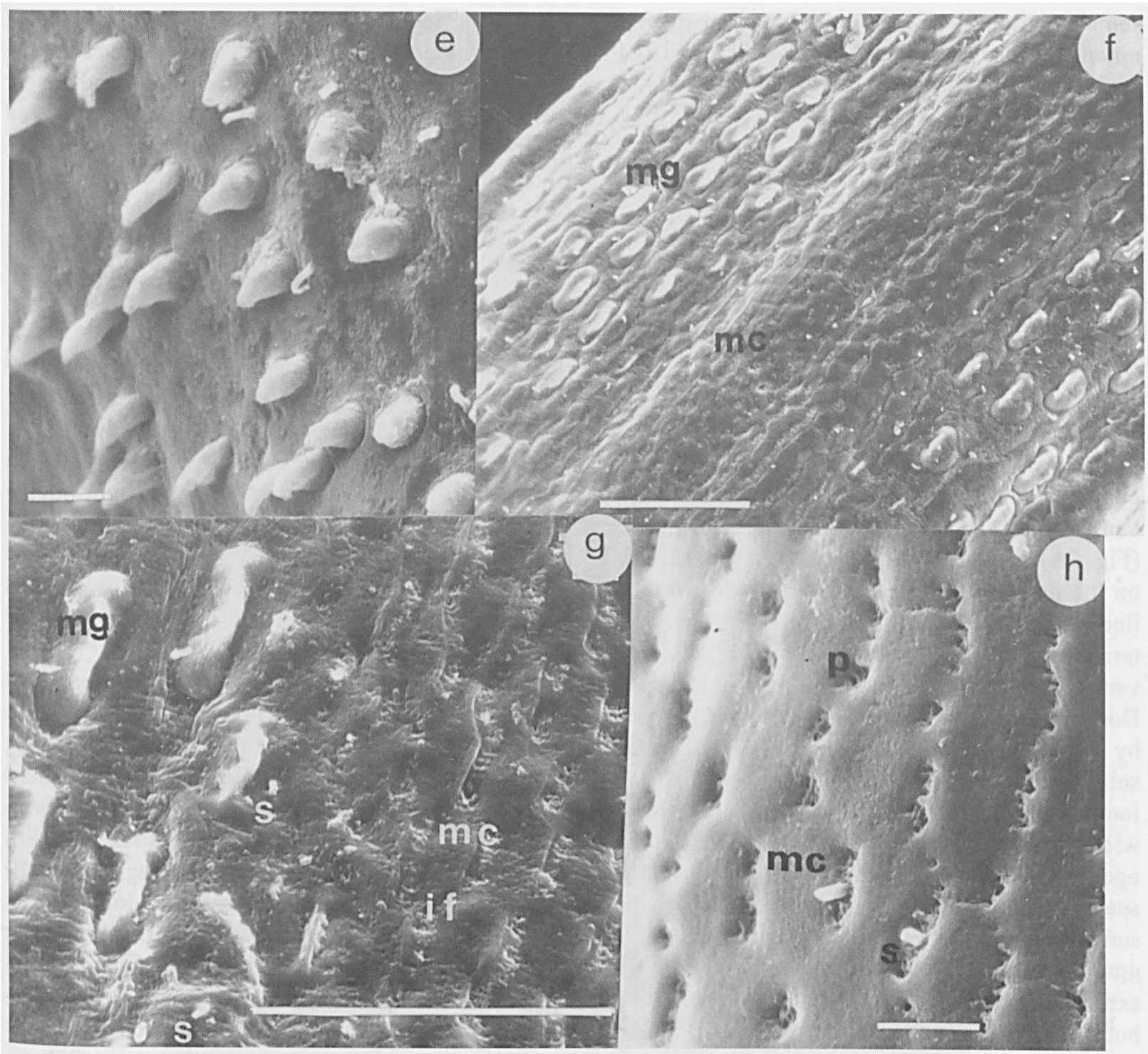

Fig. 4. Gordionus wolterstorffii, male. E, detail of the postcloacal spines; $F$ and $G$, cuticle of the lateroventral area; $H$, cuticle of the dorsal area of the body. co, cloacal opening; if, interareolar furrow; mg, adhesive warts (or "lateral blumps"); mc, areoles; 1, lobes; $p$, pores; pb, precloacal bristles; ps, postcloacal spines; s, spines. Scale bars of $A=500 \mu \mathrm{m} ; \mathrm{B}, \mathrm{C}, \mathrm{D}, \mathrm{F}$ and $\mathrm{G}=100 \mu \mathrm{m} ; \mathrm{E}=10 \mu \mathrm{m} ; \mathrm{H}=20$ $\mu \mathrm{m}$.

mountain river (Table 2). Known from a number of Coleoptera hosts, mainly Carabidae (SchmidtRhaesa, 1997).

\section{Genus Paragordius Camerano}

Type species Filaria tricuspidata Dufour, 1828

Camerano (1897: 400)
Diagnosis. - Anterior end distinctly tapered. Posterior apex of males bilobed, with long and narrow lobes. Cloacal opening oval, without circumcloacal spines or bristles, but with short acute postcloacal bristles covering also the inner side of the terminal lobes. Some species (e.g. the European $P$. tricuspidatus (Dufour, 1828), and the American P. varius (Leidy, 1851) and $P$. esavianus (Carvalho, 1942)) have precloacal bristles extending anteriorly along the longitudinal ventral sulcus. Posterior end of 
females trilobed, with terminal cloacal opening among the lobes. Cuticle similar in both sexes, with poorly defined, shallow areoles.

\section{Paragordius tricuspidatus (Dufour, 1828) (Fig. 5)}

Filaria tricuspidata Dufour (1828: 228)

"Dragonneau de Claix" Charvet (1834)

Gordius tricuspidatus Meissner (1856)

Gordius gratianopolensis Schneider (1866)

Gordius trilobus Villot (1874)

Paragordius tricuspidatus Camerano (1897)

Diagnosis. - Dimensions as in Table 1. Male: body colour dark brown, with an evident longitudinal ventral sulcus, particularly at the posterior apex (Fig. 5A). Medial longitudinal sulcus well defined on the posteroventral side, flanked with compact lines of bristles in its apical third; central and anterior parts of the body with less well developed ventral sulcus, with no marginal bristles (Fig. 5E). Dorsal sulcus not evident. White calotte, bordered by a darker collar, on the anterior apex. Mouth subterminal. Posterior apex bilobed, with two very long cylindrical lobes (533 $\mu \mathrm{m}$ long and $166 \mu \mathrm{m}$ wide in the specimen studied) (Fig. 5A). Cloacal opening oval, dimensions $58.6 \times 27.5 \mu \mathrm{m}$ in the specimen studied, without circumcloacal bristles, surrounded by smooth cuticle (Fig. 5B). Small (7.4 $\mu \mathrm{m})$ conical adhesive warts, regularly aligned, extending anteriorly for approximately $40 \mathrm{~mm}$ at both sides of the ventral sulcus (Fig. 5A). Sparse acute bristles extending towards the apex of the lobes on their inner side (Figs. 5A, B).

As observed with the light microscope, cuticle apparently not totally covered with areoles, which are arranged in small groups of 8 to 10, sometimes linearly disposed. Interareolar space granulated, with a very irregular surface, with round pores. Short and broad tubercles on the surface of the areoles, which are in general polygonal and irregular (some of them appear round).

When observed with SEM the cuticle has a very different appearance: areoles not well defined, forming irregular elevations of the cuticle with length from 15.8 to $21.6 \mu \mathrm{m}$, and width from 8.3 to $12.5 \mu \mathrm{m}$ (Figs. 5C, E). Many of the areoles with a central depression, surface covered with tubercles $3.3 \mu \mathrm{m}$ height, with the appearance of scales, arranged transversely with respect to the body axes. Interareolar spaces with pores of different sizes (from 3.7 to $11.8 \mu \mathrm{m}$ ), surrounded by a cuticular rim formed by circular fibres and very scarce tubercles with an acute apex. Cuticle covering the terminal lobes with a different structure, with less well defined areoles and a smoother, more homogeneous appearance (Fig. 5D).

Remarks. - The placement of the European species of Paragordius is controversial, as already noted Schmidt-Rhaesa (1997), partly due to the lack of detail in the original descriptions, which were all based on observations with light microscope - which are in agreement with our observations (see e.g. Fig. 1 in Camerano, 1887, with groups of areoles forming lines or clusters). However, as seen above, the details of the structure appear very different when studied with SEM.

The two European species, $P$. tricuspidatus and $P$. stylosus (Linstow, 1883), were considered to be synonyms by Camerano (1897) and Dorier (1930). On the contrary, Heinze (1941) noted clear differences in the posterior end of the males, with $P$. stylosus lacking precloacal bristles but with numerous spines in the postcloacal region extending to the ventral side of the terminal lobes, while $P$. tricuspidatus has lines of bristles flanking the cloacal opening, extending anteriorly and posteriorly on the internal side of the terminal lobes, as well as postcloacal bristles. The cuticle is similar in both species, although $P$. stylosus does not have pores.

These differences allow us to identify the specimen studied as $P$. tricuspidatus, although more studies on the taxonomic status of European Paragordius are clearly needed, in particular SEM study of the cuticle of $P$. stylosus.

Dorier (1930) considered $P$ varius (so far recorded only from America, see e.g. Leidy, 1851; Montgomery, 1898, 1903; May, 1919; Carvalho 1942; Miralles \& de Villalobos 1993; de Villalobos et al., 2000) to be a synonym of $P$. tricuspidatus. However, the cuticle of both species is clearly different, with $P$, varius having bristles and pores in the areoles and in the interareolar spaces, and 


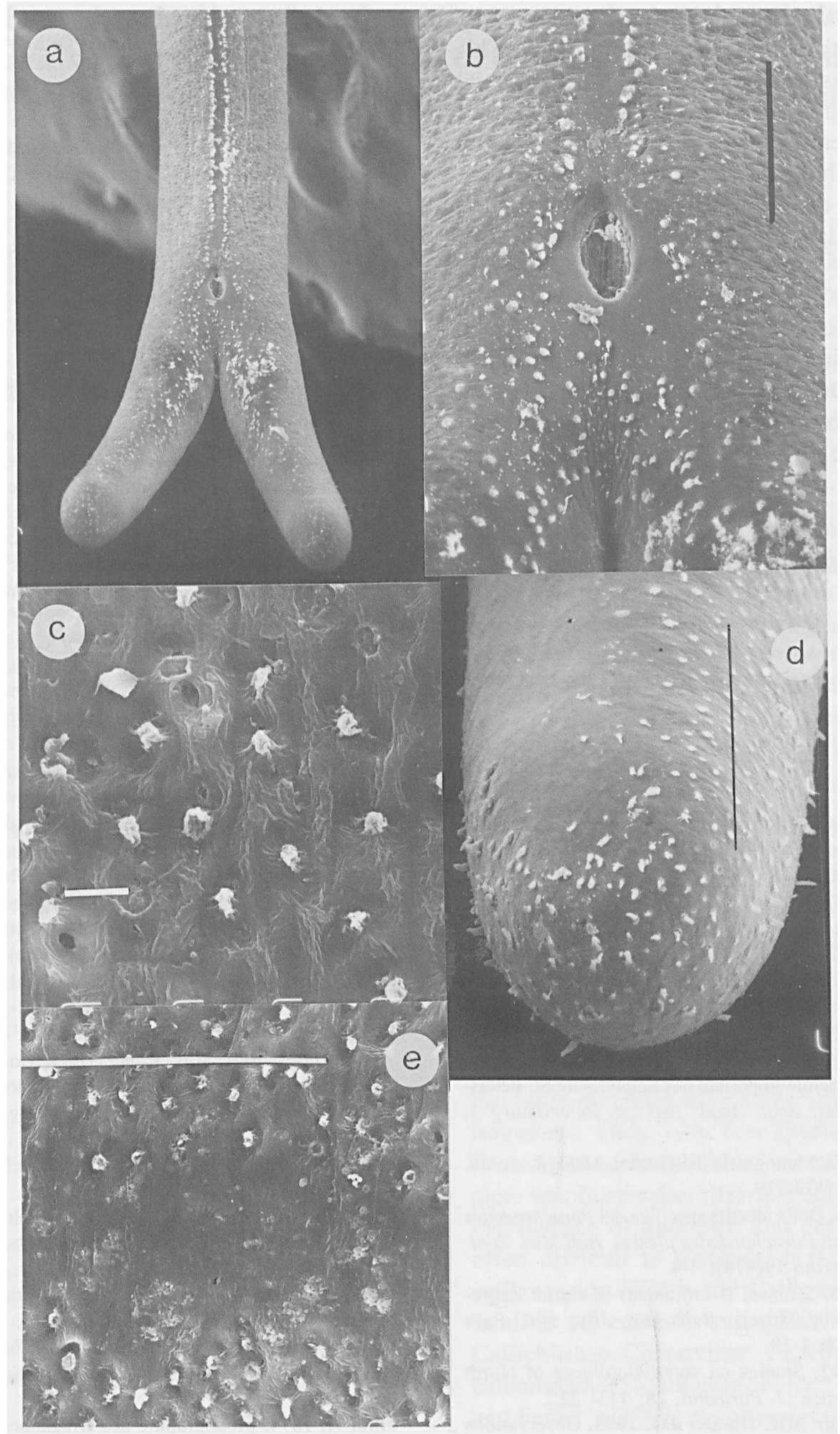

Fig. 5. Paragordius tricuspidatus, male. A, posterior end; B, cloacal opening, with precloacal and postcloacal bristles; C, cuticle of dorsal side of the medial part of the body; D, terminal lobe, with poorly defined areoles; $\mathrm{E}$, longitudinal ventral furrow. $a$, areole; $b$, britles; co, cloacal opening; pb, precloacal bristles; $p$, porus; ps, postcloacal bristles; vf, ventral furrow. Scale bars of $A=1,000 \mu \mathrm{m}$; $B$, $E$ and $D=100 \mu \mathrm{m} ; C=10 \mu \mathrm{m}$. 
cuticular rims which seem to form stripes sometimes higher than the areoles themselves. This species also has well delimited ventral and dorsal longitudinal sulci, with numerous long bristles flanking the ventral sulcus along its entire length.

The species has a predominantly south and central European distribution (France, Switzerland, north Italy, Bulgaria, Rumania) (Schmidt-Rhaesa, 1997).

Ecological notes. - The single studied specimen was collected in a mountain river among pebbles and sand (Table 2). The hosts of the species are not known with certainty, although it is suspected to be parasitic on Orthoptera (Schmidt-Rhaesa, 1997).

\section{Acknowledgements}

We thank the Electronic Microscope Service of the Museo de la Plata (Argentina) for their help, and Andreas Schmidt-Rhaesa and Iain Downie for their useful comments on the manuscript.

\section{References}

Bairrd W. 1853. Descriptions of some new Species of Entozoa from the Collection of the British Museum, Proc. Zool. Soc. London 21: 18-25.

Camerano L. 1887. Nota intorno alla struttura della cutícula de Gordius tricuspidatus (L.Duf). Boll. Mus. Zool. Anat. Comp. Torino 2(25): 1-3.

Camerano L. 1888. Ricerche sopra î Gordiî d'Europa e descrizione di due nuove specie. Boll. Mus. Zool. Anat. Comp. Torino 3(42): 1- 10.

Camerano L. 1896. Gordiens nouveaux ou peu connus du musếe de l'Académie Impériale des Sciences de St. Pétersbourg. Ann. Mus. Zool. Acad. Imp. St. Petersbourg 1:1 117- 125 .

Camerano L. 1897. Monografia dei Gordei, Mem. R. Accad. Sci. Torino 47: 339-419.

Camerano L. 1904. Della identita specifica del Parachordodes wolterstorffi del Parachordodes pleskei. Boll Mus. ZooL. Anat. Comp. Torino 19(470); 1-4.

Canadjija S. 1956. Strunasi (Gordioidea) iz zbîrke Zagrebackog Zooloskog Museja. Bull. Mus. Hist. Nat. Pays Serbe (Ser, B) 8: 1-38.

Carvalho JC. 1942. Studies on some Gordiacea of North and South America. J. Parasitol. 28: 213- 222.

Cham SA, Seymour MK, Hooper DJ. 1983. Observations on a British hairworm, Parachordodes wolterstorffii (Nematomorpha: Gordíidae), J. Zool. London 199: 275285 .
Codina A. 1925. El cas d'un Gordius (Verm.: Nematoides) extret del cos d'un Stauroderus (Orth.: Acrydiinae). Bull. Inst. catal. Hist. nat. 25: 61-64.

Charvet M. 1834. Deux Espéces du genre Dragonneau. Nouv. Ann. Mus. Hist. Nat. Paris 3: 37-46.

De Villalobos C, Ribera I, Downie S. 1999. Hairworms found in Scottish agricultural land, with deseriptions of two new species of Gordionus Muller (Nematomorpha: Gordiìdae). J. Nat. Hist. London 33: 1767- 1780.

De Villalobos C, Ramirez G, Chavarria S, Zanca F. 2000. Cuticular ultrastructure of Paragordius esavianus Carvalho and $P$. varius (Leidy). Proc. Acad. Nat. Sci. Philadelphia 150: 135- 144.

Dorier A. 1930. Recherches biologíques et systématiques sur les Gordiaces. Trav. Lab. Hydrob. Pisc. Univ. Grenoble 22 anné: 1-183.

Dufour ML. 1828. Observations sur une nouvelle espèce de vers du genre Filaria. Ann. Sc. Nat. Se.1 14: 228.

Gerlach SA. 1978. Nematomorpha. In Illies J. (ed.) Limnofauna Europaea. Sttutgart: Gustav Fischer, pp 50-53.

Heinze K. 1937, Die Saitenwürmer (Gordioidea) Deutschlands. Eine systematisch-faunistische Studie über Insektenparasiten aus der Gruppe der Nematomorpha, Z. Parasitenk. 9: 263344.

Heinze K. 1941. Saitenwürmer oder Gordioidea (Nematomorpha). In Dahl F, ed. Die Tierwelt Deutschlands. Vol. 39.3. Jena: Gustav Fischer, 1-78.

Leidy J. 1851. On the Gordiaceae. Proc. Acad. Nat. Sci. Philadelphia 5: 266.

Linnaeus C. 1758. Systema Naturae, $10^{\text {th }}$ ed. Holmiae: Laur. Salvii.

May HG. 1919. Contributions to the life histories of Gordius robustus Leidy and Paragordius varius (Leidy), Illinois Biol. Monogr. 5: 1- 119.

Meissner G. 1856. Beiträge zur Anatomie und Physíologie der Gordiaceen. Z. Wiss. Zool. 7: 1-140.

Miralles DB, de Villalobos C. 1993. Gordioidea: Distribuciớn en la Argentina y La Región Neotropical. Fauna de Agua Dulce de la República Argentina. 13(2-3): 5- 32 .

Montgomery TH. 1898. The gordiacea of certain american collections. Bull. Mus, Comp. Harv. Coll. 32: 23- 59.

Montgomery TH. 1903. The adult organisation of Paragordius varius (Leidy). Zool. Jahrb. Anat. Ontog. Tiere. 18: 387474.

Müller GW. 1927. Über Gordiaceen. Zeitschr. Morph. Okol. Tiere 7: 134-219.

Schmidt-Rhaesa A. 1997. Nematomorpha. Vol, 4/4. In Schwoerbel $J_{\times}$\& Zwick P. (eds) Süßwasserfauna von Mitteleuropa. Stuttgart: Gustav Fischer, 1-124.

Schmidt-Rhaesa A. Variation cuticular characters in Nematomorpha: studies on Gordionus violaceus and $G$. wolterstorffit from Britain and Ireland. Syst. Par, in press.

Schneider A. 1866. Gordius. In: Monographie der Nematoden. Berlin.

Villot A. 1874. Monographìe des Draganneaux. Arch. Zool. Exp. Gen. 3: 39-72, 181-238.

Received: 30 October 2000 